\title{
THE EDUCATION OF THE TAHFIDZ AL-QUR'AN IN THE INTEGRATED ISLAMIC ELEMENTARY SCHOOL "CENDEKIA MULIA" PONDOK PESANTREN AL-HUSNA TEMANGGUNG, CENTRAL JAVA, INDONESIA
}

\author{
Zainal Arifin \\ e-mail: zainal0920@yahoo.co.id
}

\begin{abstract}
The objective of this present research is on revealing the thoughts possessed by the Kyais in Pondok Pesantren Tahfidzul Quran Al Husna and on the approaches and methods adopted in this Pesantren in memorizing al-Qur'an. It is a qualitative method with the research type of phenomenology and case. The techniques of data collection were in depth interviews, observations and documentation. The data were descriptively and qualitatively analyzed and reinforced with the validity test using data triangulation. The research results are as follows. Firstyly, The education of Tahfidz al-Qur'an in pesantren tahfidzul Qur'an al husna Temanggung Central Java is based on six basic philosophies of the thoughts of the management on the education of tahfidz al-Qur'an are that memorizing al Qur'an (1) as the life capital, (2) the base of behavior, (3) the social integrity, (4) the high-quality basis o for Muslim intellectuality, (5) as the demand and need of the modern era of Islam and (6) the realization of a muslim to the al-Qur'an. Secondly, the approaches adopted in Pesantren AL Husna to facilitating the memorization of the Holy Quran are as follows: Secondly, the approaches adopted in Pesantren al Husna in facilitating the memorization of al-Qur'an are as follows: (1) taisir, starting from the easiest; (2) operational, implementing any activities that may motivate the memorization so that they are not bored with memorizing al-Qur'an; (3) psychological, fulfilling the children's rights as individuals who are still at the level of development, and (4) tazkiyah, formulizing some tarbiyah programs that may approach the children to Allah so that they are blessed in memorizing al-Qur'an.
\end{abstract}

Keywords: Al-Qur'an, Memorization, Tahfidz, Education, Pondok pesantren

\section{A. INTRODUCTION}

For a muslim, al-Qur'an is a book serving as the main source of Islamic teachings and is a guide given by Allah swt to the Prophet Muhammad saw for all mankind. In al-Qur'an, Allah swt addresses human mind and feelings, teaches tauhid, purifies them using various worships, shows them anything bringing about goodness and benefits in individual or social life and guides them into a noble religion, so that human beings may actualize themselves, develop their personality, and improve themselves to a human completeness. ${ }^{1}$

\footnotetext{
${ }^{1}$ Al-Nawawi, at-Tibyan fi hamalatil Qur'an (Adab Penghafal al-Qur'an), (Solo: alQowam, 2015), 2.
}

According to Abu Ammar, ${ }^{2}$ learning al-Qur'an as the Prophet did had succeeded in changing their comrades' personality totally and in forming them as real muslims who were then able to change the face of the history with al-Qur'an. AlQur'an has produced great many men in various fields. In the field of leadership, it has born sincere, honest, just, trusted, competent and loving leaders such as Abu Bakar, Umar bin Khathab, Usman bin Affan, dan Ali bin Abi Thalib. In the field of war, it has given birth sincere, competent, firm, discipline, brave and responsible warlords as shown in the figures such as Abu

\footnotetext{
${ }^{2}$ Abu Ammar. Negeri-negeri Penghafal alQur'an, (Solo: al-Wafi, 2015), 51.
} 
Ubaidah bin Jarrah, Sa'ad bin Abi Waqash, Khalid bin Walid, Amru bin Ash and others. In the economic field, great entrepreneurs with their great sincerity, honesty, trust, disciplinary, charity, and great care and high indulgence to help others such as Usman bin Affan, Abdurrahman bin Auf, Thalhah bin Ubaidillah, Sa'ad bin Abi Waqash, and the like has also been produce. Moreover, in the missionary endeavors, al-Qur'an has also supplied ulema and proselytizers with great sincerity, diligence, adequate knowledge, and modesty as shown in the figures such Abdullah bin Mas'ud, Abdullah bin Umar, Abdullah bin Amru bin Ash, Abdullah bin Zubair, Abdullah bin Abbas, Zaid bin Tsabit, Ubay bin Ka'ab Muadz bin Jabal, and the like. Moreover, the al-Qur'an has born a generation of Muhajirin and Anshar with strong faith, noble character, halal livelihood, and solid social life. Their legs are on the earth, but their souls and spirits reach the sky. They are able to balance between material and spiritual, personal and social and also world and hereafter lives. ${ }^{3}$

According to Ulwan, ${ }^{4}$ a child is the mandate given to their parents. His heart is still clean, holy, and sincere and is empty from any carvings and drawings. He always accepts anything carved on him and will tend to follow anything that influences him. Therefore, if he is habituated and taught to do goodness, he will do anything good. This will make the parents happy either in the world and hereafter. However, if a child is

\footnotetext{
${ }^{3}$ Sayyid Quthub, Ma'alim fi ath-Thariq, (Yogyakarta: Darul Uswah, 2011). 32.

${ }^{4}$ Ulwan, Tarbiyatul Aulad, (Solo: Insan Kamil. 2015). 105.
}

habituated to do wickedness and is neglected like a wild animal, he will suffer from unluckiness and misery. His sin will be born by the parents, since it is the parents who have been given mandate by Allah swt. $^{5}$

The education of al-Qur'an is important to be given to children at the age of 6-12 years as an effort to form Islamic personality in the children, namely those with the belief in Islam as the foundation in their thinking and their behaviors in living the life. ${ }^{6}$

At present, due to their limited time to control the children, their business and less time to meet the children, the parents usually give the religion education of their children to trusted institutions to guide the learning of religion or alQur'an. The children are usually sent to study in such institution at the early age.

A child' ability to memorize something starts from his childhood, namely when he starts learning and then mastering speaking skill, after his age is three year. However, the ability to memorize is different between one child and another. The most important thing is that one should start, routinize, behave patiently, and look for merits in guiding children to memorize al-Qur'an. ${ }^{7}$

\footnotetext{
${ }^{5}$ Muhammad Hambal. 2015. "Deresan" Program the Mastery of Arabic-Classic Book at Pondok Pesantren Karangasem Lamongan East Java Indonesia. Journal of Social Sciences and Humanities, Vol. 1,

No. 2, pp. 125-130

${ }^{6}$ Muhyidin, Mengajar Anak Berakhlak alQur'an, (Bandung: PT. Remaja Rosdakarya. 2008). 24

${ }^{7}$ Baduwailan, 9 Panduan Cepat Menghafal al-Qur'an, (Jogjakarta: Diva Press, 2012), 231
} 
The capability of a child to memorize reaches his greatest and srongest intensity at the age of 6 15years.at this age, a child may accomodate the highest number of memory materials. Consequently, those with sincere intentions to look for ridha from Allah and high posision in the heaven will habituate their children to memorize al-Qur'an since their children are in childhood. At this childhood, children still do not have any activities that may drain their mind that may hinder them to memorize. There is an adagium: memorizing at the childhood is like carving on the stone. ${ }^{8}$

Reflecting to the ulemas at the golden age of Islam such as Imam Syafii, Ibnu Sina and the like, they were ulemas who stepped on a strong foundation of tahfidz. Imam Syafi'i, a founder of Syafiiyah madzhab giving a great influence the people in Indonesia, had been able to memorize alQur'an since he was 7 years old. Ibnu Sina, an expert in medicine, memorized al-Qur'an since he was nine years old. It shows that tahfidz al-Qur'an is very important to serce as the scientific foundation in the field of religion and other sciences. Past ulemas conditioned the memorization of al-Quran as the preliminary learning before studying other sciences. ${ }^{9}$

It is not an easy task to implant or teach children to love and memorize al-Quran. Therefore, the writer is interested in studying the methods of tahfidz al-Qur'an

\footnotetext{
${ }^{8}$ Baduwailan, 9 Panduan Cepat Menghafal al-Qur'an, (Jogjakarta: Diva Press, 2012), 254

${ }_{9}^{9}$ Muhammad Hambal, Ensiklopedi Khatib, (Solo: al-Qowam, 2012), 35
}

implemented in Pondok Pesantren Tahfidzul Qur'an Al Husna Temanggung, Central Java focusing its attention to tahfidz al-Qur'an for elementary school-aged children so that it may yield children with hafidz al-Qur'an. The learning process in this pesantren was very unique where the santries and their instructors are like sons and fahers or daughters and mothers. They love one another. It can be seen that during the learning process of tahfidz, the small santries were around their ustadzs, some were hugging the backs, sitting on the hips, leaning against the bodies without reducing any respects to the ustadzs, which can be proved that when the asatidz asked them to do something, the santries listened to and obeyed them.

This kind of learning process is adopted by the asatidz because they realize that children still needs affection from their parents while they are stayed in pondok Pesantren so that their hearts are filled in with al-Qur'an as the honor of ahlul Qur'an filling their heart with al-Qur'an as commanded by Qs Allah, alAnkabut: 49. Therefore, the title of this present research is "The Education of the Tahfidz al-Qur'an in the Integrated Islamic Elementary School Cendekia Mulia Pondok Pesnatren alHusnaTemanggung, Central Java, Indonesia".

\section{B. RESEARCH METHOD}

A qualitative approach was employed, where its findings would be obtained through a statistical procedure or other forms of calculation. Qualitative means that this research is intended to understand a phenomenon on what is 
experienced by the research subject, for examples, behaviors, perceptions, motivations, actions and the like which are described holistically and are presented in the form of words and language at certain natural contexts making use of various scientific methods. ${ }^{10}$

This present research is intended to answer to the question about how an event happens and to report the results as they are. Through this research, it is expected to describe the management's thoughts about the philosophical basis of the education, the approach, and the learning method in tahfidz alQur'an, in Pondok Pesantren Tahfidzul Qur'an Al Husna.

The data employed were two types, namely primary and secondary. Primary data in this research were obtained from the headmaster and the director or kyai as the policy makers in the pesantren. While the secondary data were documents in the pesantren such the vision, the missions, the history, and the various activities held in the pesantren.

To get clear, accurate, and complete information, some data collection techniques were employed, namely observations, interviews, and documentations.

\section{RESEARCH RESULTS}

\section{Approach to Tahfidz al-Qur'an}

Approach is something that is absolutely made as an effort to facilitate a process of reaching tahfidzal-Qur'an. The approaches adopted in Pesantren

\footnotetext{
${ }^{10}$ Ulfatin, Metode Penelitian Kualitatif di Bidang Pendidikan: Teori dan Aplikasinya, (Malang: Banyu Media Publishing, 2014), 24
}

Al Husna among others are as follows:

\section{a. Taisir Approach (Starting from the easiest)}

Memorizing 30 juzs (sections) is like climbing the highest mountain. If this heavy practice is felt to be light, the pesantren asked the santries to start from the easiest from 30 juzs namely juz 'amma because its surrahs are short and familiar. It was intended to train and to habituate the beginners. But, this was not continually done. Pondok Pesantren Al Husna made this policy with the reason that memorizing, if it starts from the back mushaf (manuscript), juz 'amma or mostly five juz from the back, namely juz 30, 29, 28, 27 and 26 since the verses are familiar.

\section{b. Operasional Approach}

This approach was adopted by the management of the pesantren as an effort to give spirits to the santries to memorize and to do other activities in pesantren.

Since this pondok is special for children, anything motivating them is needed to encourage them to learn $o$ memorize al-Qur'an, for example by holding sima'an exam once week which is a challenging activity, because this forces them to be able to do their tasks, otherwise they are is ashamed. Therefore, they would try their best to prepare their memorization well. Moreover, this activity is also intended to create an environment conducive to the implementation of their love to 
al-Qur'an, and to provide the santries with special books containing information of their health, cleanliness, orderliness, discipline, and smartness which is evaluated each month.

\section{c. Psychological Approach}

This approach is very important to implement as an effort to fulfill students; right as individuals who are still at the early stage of development.

It is implemented by giving them specific time to play namely before maghribh, outbound or relaxation once a month, and also murobbi ustadzs who are the representation of the parents.

\section{d. Tazkiyah Approach (Innner Purification)}

This approach really influences the santries' success in memorizing al-Qur'an. Since al-Qur'an is kalamullah, one's closeness to Allah gives much effect on his success. Consequently, Pesantren Tahfidzul Qur'an Al Husna has formulizes some tarbiyah programs to do some tazkiyah to the santries so that they will be given some easiness in memorizing Kalamullah. The tarbiyah programs among others are as follows.

1) Qiyamul lail

Qiyamul lail is a must for the santries since it may activate the heart and enlighten the face to anyone who does it. It is states in the following

Allah's commandment: "Verily, the rising by night (for Tahajjud prayer) is very hard and most potent and good for governing (the soul), and most suitable for (understanding) the Word (of Allah)" (QS. Al-Muzammil: 6). The Prophet Muhammad saw also says: "When one who is memorizing al-Qur'an read in at night and day, one will remember it. But when one does not do that, one will forget it." (HR. Muslim).

Therefore, the santries in this Pesantren are awaken at 03: 30 a.m one hour before Subuh praying so that they may do qiyamul lail.

2) Sunnah fasting: Monday and Thursday

The santries in

Pesantren al-Husna are also required to do fasting Monday and Thursday $\mathrm{s}$ to make their soul nearer with Allah and be given facility in memorizing al-Qur'an.

\section{Tahfidz al-Qur'an Method}

Guiding school-age children to memorize al-Qur'an is easy since their memory is still strong. This according to Ubaid (2015: 85) is caused by two main reasons. Firstly, children accept various knowledge without any solution or any filter to the knowledge. They will not do any "filterization", a method of problem solving through which one does in line with the stages of one's age. When one is mature, he will start feeling some doubt of each knowledge one receives and he solves it by looking for any solutions. In one occasion, he would refuse it totally. Secondly, children do not have this anxieties, worries, and turmoil which are felt by adults.

However there is some difficulty in asking them to 
memorize al-Qur'an namely it really needs patience since they are still immature. Therefore, Pondok Pesantren Al Husna adopted some methods in guiding the hafidz al-Qur'an, namely:

\section{a. Taghanni Method (intoning al-Qur'an reading)}

School-aged children like to sing, so to facilitate them in memorizing verses of alQur'an, the verses are intonated by paying attention to the rights rules of their tajwid. By this method, they may memorize them without any burden and any feeling of boredom because it is in line with their tendency.

Pondok Pesantren alHusna has determined the official intonation of the alQur'an reading to follow the intonation of Muriqi and Yusuf Kalo. Yusuf Kalo is a young hafidz from Arab who has been very popular in Indonesia. His reading intonation is melodious so that it is easily imitated by the santries. As a result, his record is always played during their leisure time to make them be habituated with the reading intonation.

\section{b. Talaqqi Method}

It is the act of studying al-Qur'an from a teacher so that the students know the right way of reading. The teacher is teaching al-Qur'an by memory or by reading the book, then the students read it in front of the teacher.

The steps in practicing this method are as follows: The teacher determined the number of verses that would be memorized by the halaqah students. The teacher read the verses to memorize to the students, then each student read them one by one in front of him/her/. There are many positive sides in this method, among others are as follows:

1) Improving the quality of reading and the attention to the rules of tajwid and reminding all students to be silent to listened to the teacher's or one of the students' reading. After the modeling, a student with better reading ability is appointed to read it first, then the turn is given to the student with lower ability, and so on. This results in the students with lower ability to be able to learn reading from the student with higher ability.

2) Reducing the level of lahn ( reading mistakes), either lahn jail or lahn khafi since it is very easy to know such reading mistakes made by the teacher or the students. This method also enables the students to correct their own mistakes due to many repetitions of reading verses given by the teacher and his classmates.

3) Raising the spirits and the motivation of the students whose memorization ability is slow to catch up and to imitate their 
classmates in terms of memorization and muraja'ah.

4) Facilitating the students in memorizing the verses due to the high frequency of repetitions in accordance with the number of students.

5) Facilitating the use of learning facilities, especially the board to explain the laws and to correct any mistakes because all students pay attention to one thing. By this method, a teacher's ability in monitoring the students' verses that have been memorized, readings and students will be better than other methods.

6) Enabling teachers to explain the meanings of obscure sentences or verses that should be read; asking the students to read a verse together.

7) Assisting the halaqah teachers employing the method in making any policies beneficial for the management of the foundation.

\section{c. Al-Qasimi Method (Repeating readings in 40 times)}

In this method, the santries were asked to read a verse at least 40 times before memorizing it. Reading 40 times before memorizing is actually included into the process of memorization. After reading 40 times, the santries started memorizing it with the following reasons:
1) We are instructed/required to read al-Qur'an with correct reading altogether and it may be fulfilled by reading a lot, before, during or after memorization.

2) In al-Quran there are 6236 verses, 604 pages, 302 pieces of paper, 77.439 words, 340.740 letetrs, where each letter has five characteristics and maximumly seven characteristics. Each letter or word has tajwid law. Reading a lot will lessen mistakes or forgetting.

3) For long-term memorization.

4) For collective memorization.

5) For facilitating the brain's work.

6) For enabling the subsconscious mind may memorize well.

7) For natural memorization.

8) In the 40 times in tartil readings, the reflex to memorize al-Qur'an may then result in some reflexes to read it correctly.

9) Following the trace of those memorizing alQur'an in the past or salaf generation.

10) Reading a lot is a good foundation.

11) To avoid or reduce mistakes and forgetting when showing memorization in front of the etachers.

12) For introduction or warming up before memorization. 
13) To know lafadz-lafadz that will be memorized.

14) The Order to read will be lighter or comfortable to hear, or easierto do then the order to memorize.

15) Making readings quiter, more lively

16) To attain good memorization

17) To facilitate the memorization of page numbers

18) To facilitate the memorization of verse nmbers

19) To result in high quality memorization

20) To have more khatams of al-Qur'an.

21) To make our time give more usefulness with dengan al-Qur'an.

In this method, there are three phases in reciting alQur'an: phase one, reading 40 times, phase two, memorization, and phase three, repetition. The ustadzs in Pondok Pesantren al Husna explained why this method requires the santries to read a verse to be memorized 40 times before memorizing it.

d. Fardi Method (memorizing individually in accordance with one's ability)

The implementation of this method is as follows: the teacher gave opportunities to the students to compete to memorize al-Qur'an after they passé talaqqi and tilawahs stages. Alls students memorized them in accordance with their abilities Allah blessing to them and with their efforts they have made to realize their memorizations under their teachers' guidance and advices.

To add new memorizations, the santries were given some freedoms in line with their ability and the most important thing is that the target in each level is attained. Among the students, there were students who memorize a half page, one page, even two pages each

\section{e. Muraja'ah Method}

This method is used to bind any memorizations. In Pesantren al-Husna, it consist of Sabak, Sabki and Manzil methods. Sabak is new memorization today. Sabki is the repetition of the yesterday memorization butstill one juzwith sabak. Manzil is the combination of the two and repetition of the long-standing memorizations, namely juzs besides sabak and sabki. It is what is called a chained memorizations. If one has memorized a new verse to day (sabak), he should repeat the verse presented yesterday, and also old memorizations (manzil).

\section{DISCUSSION}

The descriptions above have shown that thoughts of the management of Pesantrean al-Huna, especially KH. Zamakhasyasi on the education of tahfidzul Qur'an. He is a person with full of spirit in producing the hafidz (memorizers of al-Qur'an), especially children with the hope that they may grow to become the pioneers of umah such as 
Imam Safii and Ibnu Sina and other scientists who had been able to memorize al-Qur'an before adults. They have color the history of Islam in the golden era. They thought that the best education for children starts fro the education of al-Qur'an, since al-Qur'an is the best educator.

It is in line with Daduwailans' (2014: 197) view that teaching alQur'an is one of the cores of Islam, so that children grow above the natural tendency and the light of wisdom flowing into the heart, before their black stain and lust residing in their clouded immorality and digression. The Comrades had experienced the importance of memorizing al-Qur'an and its influence to the minds of their children. As a result they taught alQur'an to their children before they learned other matters because the education of al-Qur'an is the best education as stated by the Prophet Muhammad saw: "The best of you is those studying and teaching alQur'an an" (HR. Ahmad and Tormidzi).

The same vein is also stated by Mukhtar (2016:n182) that memorizing al-Qur'an is the base of talaqqi al-Qur'an as stated in Allah's commandment: "Rather, the Qur'an is distinct verses [preserved] within the breasts of those who have been given knowledge. And none reject Our verses except the wrongdoers. (QS. Al-Ankabut: 49). When explaining this verse, he commented that actually the process of conveying al-Qur'an is depended upon the memorization in the heart and breast, instead of the writings in the manuscripts and books. It is the superiority from Allah for this ummah. In memorizing al-Qur'an, modeling comes from salafush- shalih as the base of all bases and of point of departure from all matters. They are the basic reference for all methods and scholars and will not start their learning except memorizing al-Qur'an first. As a result, if we once read biography of one of the scientists, we would find that in his life he had memorized alQur'an first, then started learning science. The majority of salafs refused to teach hadits and other sciences to youths, except after the youths have memorized al-Qur'an. Ibnu Jamaah entered the memorization into his first courtesy of other courtesies adopted by the learners of science: "He should start with Kitabullah, making himself skillful with memorization, and really go into deep the commentary and the whole sciences, since alQur'an is the basis, the parent, and the core."

The ulemas' opinion escorts the researcher to a conclusion that the way to educate children is to become great ulemas and scientists like those in the golden era of Islam that have carve their names in the history of Islam and produced great works should come from the epistemologycal base of al-Qur'an that has been memorized by heart since they are childhood. Then they are motivated to continue studying sciences that reinforce their understandings as the medium to deepen various sciences in line with their talent and interest so that they will become scientists in accordance with the fields. Therefore, later competent scientists under the framework of piety to Allah swt would emerge, scientists will noble characters in worshiping to Allah swt and in socializing with human beings. 
The methods of tahfidz al-Qur'an adopted in Pesantren al-Husna are Taghanni, Talaqqi, al-Qasimi (repeating readings for 40 times), Fardi (memorizing individualy according to one's ability), Muraja'ah (always repeating memorizations), all involving elements of senses. According to the researcher, to be able to memorize al-Qur'an well, quickly and longlastingly, the brain should be adjusted to the style of memorizing involving elements of senses of sight, hearing and of taste, or they are called auditory, visual and kinesthetic elements.

One of the five senses are ears as the tool for listening which, according to Yayan (2015: 41) in alQur'an are called "al-udzun". This term and its all changes are called 15 times. Allah calls this term to remind Man on the importance of listening to Allah's verses. In Al-Qur'an it mentioned tha ears are the first organ which is held responsibility, after eyes and hearts (QS. Al-Nahl: 78 and al-Isra': 36). This shows that hearing is the first organs of the body that receives information in the memory, then puts it in the brain. Optimalizing hearing (ears) for the memorizers of al-Qur'an gives many advantages, since all methods of memorizing it are from it.

It is in line with the sima'I and talaqqi adopted in Pesantren alHusna. This pesantren, according to the researcher, may be called to be an ideal pesantren for kids since in terms of the method adopted, it has unique methods that may make children easy to memorize al-Qur'an. Taghann method makes the students not be boring with memorizing alQur'an and strengthening memorizations by listeing the reading al-Qur'an a lot using the reading intonations by Yusuf Kalo, Murqi, that have been determined as the official reading intonation adopted in the Pesantren. Al-Qasimi method has its own strength, namely the santries are used to memorizing verses to memorize so that this facilitates the process of memorization. This is also the case for muraja'ah method with the sabki, sabak and manzil systems that cause the santries not to forget old memorizations since this method always relates the new memorization to the old ones.

Dealing with the approach adopted, this pesantren also has paid attention to children's psychological condition namely, they still want their parents' love. Therefore, this pesantren has provided them with murrabi ustadzs and given them times to play so that their cheerfulness in memorizing alQur'an may always be maintained.

In the learning system in this Pesantren, an effort is made to combine the religion education and the general one. It can be seen from the fact that the santries are educated to memorize al-Qur'an, and also obliged to join in the teachinglearning processin general sciences in the Integrated Islamic Elementary School Cendekia Mulia. This condition is in line with $\mathrm{KH}$. Zamakhsari's expectation that children who become the memorizers of al-Qur'an may be engendered, children that will be muslim scientists as happened in the golden era of Islamic education like Imam Syafii, Ibnu Sina and other scientists. They are muslim scientists stepping the legs on the strong tahfidz foundation. Imam Syafii, an ulema with Syaffiyah madzhab, is 
influential in Indonesia, he had memorized al-Qur'an since he was 7 years old. Also, Ibnu Sina, an expert in medicine, had memorized alQur'an since he was 9 years old. Therefore, Pesantren al-Husna may serve as the model, since in educating children it has paid attention to all educational aspects such as psychological, spiritual, and also intellectual so that it is expected that it may bear muslim scientists with hafidzs al-Qur'an.

\section{E. CONCLUSION}

On the basis of the research results, either the library research or the research in the field, and the analysis and the discussion presented in previous chapters, the followings is presented some conclusions which are answers to the research questions:

1. The education of Tahfidz alQur'an in pesantren tahfidzul Qur'an al husna Temanggung Central Java is based on six basic philosophies of the thoughts of the management on the education of tahfidz al-Qur'an are that memorizing al Qur'an (1) as the life capital, (2) the base of behavior, (3) the social integrity, (4) the high-quality basis o for Muslim intellectuality, (5) as the demand and need of the modern era of Islam and (6) the realization of a muslim to the al-Qur'an. Secondly, the approaches adopted in Pesantren AL Husna to facilitating the memorization of the Holy Quran are as follows

2. Approaches adopted in the Pesantren al-Husna to facilitating the memorization of al-Qur'an are as follows (1) Taisir (starting from the easiest) namely juz 30 since its surrahs are short and are familiar) ; (2) Operational, by holding any activities that may motivate them in memorizing alQur'an so that the santries are not boring with their routine activities such as sima'an, by creating an environment that help promoting the love for al-Qur'an. and providing the santries with development books containing the reports of their health, cleanliness, orderliness, discipline and smartness appraised each month; (3) Psychological, fulfilling the children's rights as individuals who are still at the stage of early development by giving them special time to play, namely each time before maghrib, outbound or relaxation once a month, and murbbi ustadzs, the realization of the parents; (4) Tazkiyah (inner purification), formulizing some tarbiyah programs so that the santries are blessed with easiness in memorizing al-Qur'an.

3. Methods of memorizing al-Qur'an adopted in Pesantren al-Husna are as follows: (1) Taghanni, intonating the reading of alQur'an by paying attention to correct tajwid rules that facilitates the santries to memorize alQur'an without any burden and any boredom since at the age, children are like to sing;(2) Talaqqi, learning al-Qur'an from a teacher so that the students know the correct reading. This method is implemented where the teacher is reading al-Qur'an either by heart or seeing the manuscript, then the student read it in front of the teacher; (3) Al-Qasimi, where the santries are asked to read a verse, for example, at least 40 times before memorizing it; (4) Fardi, adding new memorizations 
by giving the santries in accordance with the ability and the most important thing is that the target of memorizations is achieved at each level; (5) Muraja'ah, binding memorizations using sabak, sabki dan manzil methods. Sabak is a new memorization to day, sabki is the repetition of memorization made yesterday but still one juz with sabak, while manzil is the combination between the two and the repetition of long-standing memorization, namely juzs memorized besides using sabak and sabki methods. If a santri has memorized a new verse today (sabak), he should repeat the verse he presented yesterday (sabki), besides repeating old memorizations (manzil).

\section{REFFERENCE}

Abu Ammar (2015). Negeri-negeri Penghafal al-Qur'an, Solo: al-Wafi.

Baduwailan, A. (2012). 9 Panduan Cepat Menghafal alQur'an, Jogjakarta: Diva Press.

(2014). Asrar Hifdzil Qur'an (Cara mudah dan Cepat Hafal al-Qur'an, Solo: Kiswah.

Hambal, Muhammad, (2012), Ensiklopedi Khatib, Solo: al-Qowam. (2015). "Deresan" Program the Mastery of Arabic-Classic Book at Pondok Pesantren Karangasem Lamongan East Java Indonesia. Journal of Social Sciences and Humanities, Vol. 1, No. 2, pp. $125-130$

Muhyidin, M. (2008). Mengajar Anak Berakhlak al-Qur'an,
Bandung: PT. Remaja Rosdakarya.

Al-Nawawi, Y. (2015). at-Tibyan fi hamalatil Qur'an (Adab Penghafal al-Qur'an), Solo: al-Qowam.

Quthub, S. (2011). Ma'alim fi athThariq, Yogyakarta: Darul Uswah.

Ulfatin, N. (2014). Metode Penelitian Kualitatif di Bidang Pendidikan: Teori dan Aplikasinya, Malang: Banyu Media Publishing.

Ulwan, A. (2015) Tarbiyatul Aulad, Solo: Insan Kamil. 